caused by the northerly winds that prevailed during the abovementioned period, and which drove the water off the coast. Just now the lowering of the atmospheric pressure, that had been as high as 778 millimetres, gave a prevalence to southerly winds, and the sea reached again its former level.

$$
\text { I. LUIGGI, }
$$

Resident Engineer $a^{+}$the Pier Works, Genoa, Italy February 28

\section{A Strange Phenomenon}

RELATIVE to the letter of Mr. James Moir, under the above title, which appeared recently in NATURE, I beg to observe that in the Highlands of Perthshire, some forty years ago, two men found themselves enveloped in flames, somewhat in the same style as Mr. Moir was on February I8 last. One Mr. John Stewart, who, for many years, drove the Mail gig between Dunkeld and Aberfeldy, told me that on a certain dark night, he and another man, climbing a rocky, heathery height in Rannock, were all at once set on flames by some mysterious fire, which appeared to proceed from the heather, which they were traversing, ard the more they tried to rub the flames of the more tenaciously they seemed to adhere, and the more the fire increased in brightness and magnitude. Moreover, the long heather agitated by their feet, emitted strea ns of burning vapour, and for the space of a few minutes they were in the greate- $t$ consternation. They believed that they barely escaped a living cremation. Of course their liberal share of native superstition, along with the weird gloom of the night in the weird wilderness remote from human habitation, rendered their position the more alarming. Mr. Stewart did not mention whether the weather was stormy or not ; but without doubt the object of their fear was St. Elmo's Fire. The ignis fatuus has heen frequently seen in these Highland districts hovering over marshes, rivers, and churchyards, which was believed by the superstitious to be the ghosts of the dead. IVhen the ignis fatuus was seen flickering over the graveyard, it was a cignwith them-that some one was to be buried there soon, and when seen floating over a river, it was a sign that some one was to be drowned there that night or soon after, the floating, wandering lights being their ghosts. Drainage, in this respect, has effected many changes.

DONALD CAMERON

45, Calder Street, Govanhill, Glasgow, March 6

Mr. JAMES MoIr, in last week's Nature (p. 4I0), mention a probable peculiar manifestation of St. Elmo's Fire, and asks if any one can give instances of a similar occurrence. About twenty years ago I was returning, during the evening, to my house from Great Yarmouth, a distance of three miles, and took the road of the Denes, intending to cross by the lower ferry. Before reaching it a dark cloud coming from the south-east, off the sea, suddenly surprised me, and drenched me with rain. I jumped into the boat, and when the boatman had pushed off, I remarked that every drop of rain hanging from my hair, beard, and clothes was luminous with white light, well seen, as it was very dark at the time. I found the same appearance had been observed by several pilots exposed to the same shower. I always attributer the occurrerce to a species of St. Elmo's fire. It was mentioned at the time by a friend of mine at a scientific meeting in London, and thought curious.

Cheltenham, March 7

W. H. C. B.

\section{Parhelia}

OF the parhelia of January 27 seen by $M$. Albert Riggerbach (NATURE, vol. xxv. p. 364) I was a spectator, and noted my observations at once. I was walking near Pavia when I observed the phenomenon about 3.45. A mock sun (one only) was in the same altitude with the sun on the horizon; M. Riggenbach's faint cirrus obviously corresponds to the filamenti nebbiosi in my note; they were as I well remember, with the mock sun in the eastern part of the sky, while in the opposite region some blackish cumuli approached slowly.

Pavia, Lombardy, February 27

\section{Red Flints in the Chalk}

ARE red flints common in the Chalk? A portion of our Colege farm l:es on a gen+le slope on the Upper Chalk, which rises westward from the banks of the Ilampthire Avoin. Cn the higher parts of this slope black flints are excessively abundant, so much so that after sheep have been folded on the land, the fields present the appearance of a newly macadamised road, and the flints are picked up and put into heaps until an opportunity offers to use them for road-metal; in the course of a year they "grow" again as thickly as before. But ose field on a ridge near the foot of the slope is remarkable for the number of red flints it contains; on the dusty soil they look just like bits of broken earthenware, and might at first fail to attract attention. Their size is much les: than the average size of the black flints ; some are rounded and some angular, others almost flake like. As to the frequency of their occurrence, I found I was able to pick up at least one at every step I took.

College of Agriculture, near Downton, Salisbury, February 28

\section{THE SALMON DISEASE 1}

FOR some years an epidemic disease, followed by a very large number of deaths, has been observed to prevail among the salmon of certain Scottish and British rivers, from the Tay, on the north, as far as the Conway on the south.

The first obvious symptom of the malady is the appearance of one or more whitish patches upon the skin of parts of the body which are not covered with scales, such as the top and sides of the head, the adipose fin, and the soft skin at the bases of the other fins.

Such a patch, when it first attracts attention, may be as big as a sixpence. It is nearly circular, with a welldefined margin and a somewhat raised softer centre, from which faint ridges radiate towards the circumference. It is important to observe that a single small patch of this kind may be seen on the skin of a fish which, in all other respects, is perfectly healthy, and when there is no indication that the skin has ever been bruised or abraded in the place occupied by the patch. The patch, once formed, rapidly increases in size, and becomes confluent with any other patches which may have appeared in its neighbourhood. The marginal area, as it extends over the adjacent healthy skin, retains its character; but the central part undergoes an important change. It takes on the consistency of wet paper, and can be lifted up in soft flakes, as if it were a slough, from the surface of the derma or true skin, which it covers. In fact, it is obvious that this papyraceous substance has taken the place of the epidermis, so that the sensitive and vascular true skin is deprived of its natural protection. As the patch spreads, the true skin beneath the central papyraceous slough ulcerates and an open bleeding sore is formed, which may extend down to the bone, while it passes outwards into burrowing sinuses.

When the disease has reached this stage it obviously causes great irritation. The fish dash about and rub themselves against. stones, and thus in all probability aggravate the evils under which they suffer. One vast open sore may cover the top of the head from the snout to the nape, and may extend over the gill covers. The edges of the fins become ragged; and, sometimes, the skin which invests them is so completely frayed away that the fin-rays stand out separately.

Although the affection of the skin appears, usually, if not invariably, to commence in the scaleless parts of the body, it does not stop there, but gradually spreads over the whole of the back and sides of the fish, though I have not yet seen a specimen in which it covered the whole ventral surface. The disease extends into the mouth, especially affecting the delicate valvular membrane attached to the inner sides of the upper and the lower jaws. It is said to attack the gills, but there has been no sign of it on these organs in any fish which I have had the opportunity of examining.

Fish which succumb to the disease become weak and

x A Contribution to the Pathology of the Epidemic known as the "Salmon Diseace." Paper read at the Royal Society, March 2, by Prof. T. H. Huxley, LL D., F.R.S. 